\title{
Assessment of category of the rock burst hazard for the Charmitan gold deposit
}

\author{
Shuchrat Mukhitdinov ${ }^{*}$, Aziz Kazakov ${ }^{1}$ and Muzzafar Khakberdiev ${ }^{1}$ \\ ${ }^{1}$ Tashkent State Technical University, 100095 Tashkent, Universitetskaja, 2, Uzbekistan
}

\begin{abstract}
The article analyzes the results of studying the physicalmechanical properties of the rocks of the Charmitan gold deposit (Uzbekistan) and estimates the liability of the deposit to rock bursts. It is shown that there are rocks and ores at the deposit with high strength properties that are capable to accumulate significant potential energy and undergo brittle failure. It is concluded that the Charmitan field, by the physical-mechanical parameters of host rocks, belongs to the category characterized by the manifestation of rock pressure in a dynamic form.

Keywords: rock burst, stress field, physical and mechanical properties of the rock, brittle failure, geomechanical condition, rock-bump hazard specific index, geodynamic hazard
\end{abstract}

\section{Introduction}

Underground mining of the mineral deposits with tough geological conditions and at great depths is associated with the increase of pressure in the rock massif. Ensuring safe and effective mining in these conditions is of great importance for development of the mining industry.

The adverse geological conditions include the heterogeneity of the geological structure, the presence of high unequal tectonic (horizontal) stresses, high rock pressure at great depths. These conditions promote the development of dynamic manifestations of rock pressure. Distinctive features of rock pressure dynamic manifestations, especially that of rock bursts and tectonic rock bursts, are their suddenness and great destructive power. Their manifestation causes significant physical and social sequences to mines and results in lengthy stoppages of operation due to the need to execute the large-scale postaccident work [1-11].

The problem of rock bursts in world's mining has existed for over 100 years. Currently, rock bursts and bumps occur in more than 70 fields globally. The strongest rock bursts were recorded at the Kolar deep gold mines in South India, the Witwatersrand deposits in South Africa, where mining operations are carried out at a depth below 3,000 m. Rock bursts have been also reported at the mines of the United States, Canada, China, Uzbekistan, they occurred in Europe in the mines of Austria, the Czech Republic, Poland, UK [12-18]. Tectonic rock bursts are accompanied by fault wall displacements with an amplitude of tens

${ }^{*}$ Corresponding author: shuhrat_m@inbox.ru 
of centimetres [19-22]. Strong rock bursts manifest themselves as earthquakes and also cause environmental damage [23-24]. Geodynamic processes affect the condition of infrastructure and communications on the surface [25-29]. In the CIS countries (Former Soviet Republics), first-ever rock bursts were recorded in the 40s of the XX century in Kizelovsky coal basin. Later, in the $60 \mathrm{~s}$, rock bursts were recorded in underground development of ore deposits (Tashtagolskoye, Oktyabrskoye, Severouralskoye bauxite mine, etc.) [1]. Hence, from the late 70s the forecast and prevention of rock bursts has become a relevant issue for a number of underground mines in the CIS, including Uzbekistan.

Literature review and data analysis shows that in any present day hypothesis of causes and mechanism of rock bump, its central core is the concept of the accumulation and abrupt release of the rock elastic energy. Specialists admit that elastic energy in the rock accumulates in the abutment zones developed at and around underground excavations. Significant distinctions between different authors in the interpretation of the mechanism for the occurrence of rock bursts are, in fact, the following questions: which key factors trigger brittle failure of rock; what is the interaction between these factors and what is the role of each factor in any given geological and mining conditions of the deposits.

\section{Analysis of the geomechanical conditions at Charmitan mineral deposit}

As is known, the key natural factors that contribute to manifestation of rock pressure in a dynamic form are:

- the ability of the rock mass to undergo elastic deformation and accumulate potential energy of elastic deformations;

- propensity of ore (rock) for brittle failure;

- high level of stresses acting on the contours of development headings, production workings and in pillars.

Deposits or their parts (mineral a' different levels) are categorized into non-hazardous, prone to rock bursts and hazardous for rock bursts [30,31]. Deposits of ore and rock with high elastic properties and brittle nature of failure are included into the 'liable to rock bursts' category.

The ability of the rock mass to accumulate elastic energy is determined by the ratio of elastic deformation and total strain at the moment when tested for compression samples of ore and rock collapse. The brittle nature of failure is understood as the ability of rock to suddenly release the potential energy of elastic deformations accumulated in the process of loading when the latter reach their ultimate stress state. The liability of rock to brittle failure is established by the ratio of the elastic modulus $\mathrm{E}$ and the drooping modulus $\mathrm{M}$, which characterizes the extreme deformations of the collapsing rock. Consequently, in order to predict hazardous dynamic effects at the Charmitan mine field (Figure 1), the first thing to do is to make an assessment of the key factors that make the greatest impact on the manifestations of ground pressure in a dynamic form. 


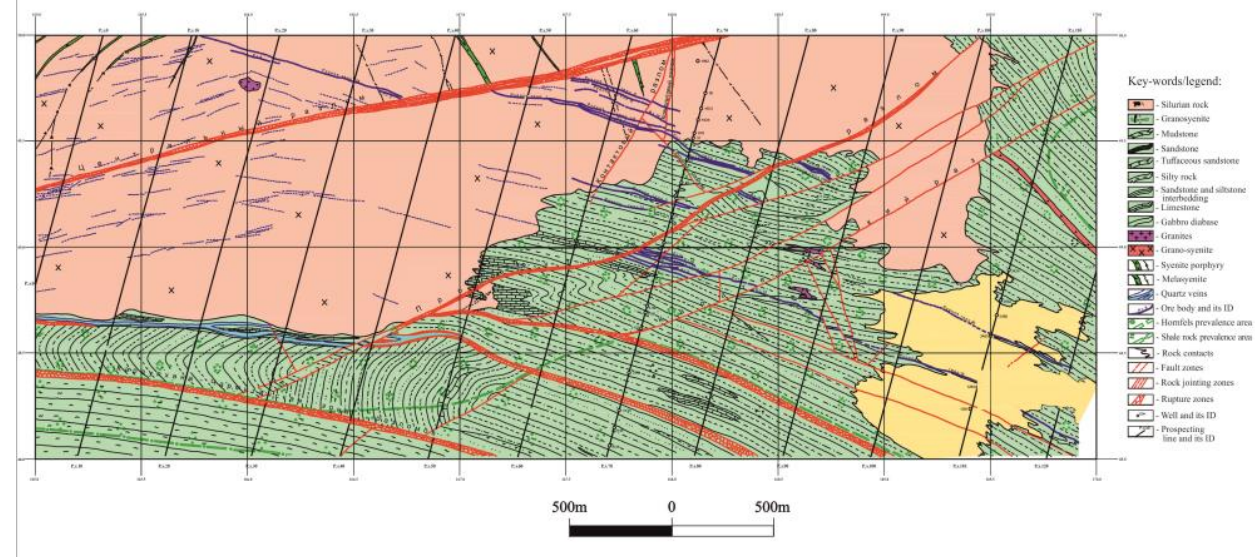

Fig. 1. Geological map of deposit

The authors studied physical and mechanical properties of the host rock of the Charmitan deposit and calculated the rock-bump hazard coefficients to determine the geomechanical condition of the field. The host rock of the Charmitan gold deposit is typically represented by quartz-mica schist, hornfels, granosyenite and syenite, Figure 1.

Faults are represented by two groups: faults that run longitudinally and parallel to the folded structures and those that run arriswise. Longitudinal faults are associated with linear mode of folding and usually confined to the fold wings. Their planes are slanted towards the general fall of the layers. Morphologically, they represent shifts.

\section{Results}

Physical and mechanical properties of the surrounding rock of the field are presented in the Table 1.

The rock-bump hazard rate for the area is defined using rock-bump hazard specific index KRB:

- over 0.8 - extra high hazard;

- between 0.7 and 0.8 - high hazard;

- between 0.6 and 0.7 - non-hazardous category.

As is obvious from Table 1, almost the entire lithological complex of host rocks and ores has a sufficiently high strength and elasticity. Uniaxial compression strength $\sigma \mathrm{cmpr}$ can be as high as 180 to $196 \mathrm{MPa}$, Young's modulus is $\mathrm{E}=(4.8 \div 8.5)^{*} 104 \mathrm{MPa}$. The rock of this field has the ability to accumulate potential energy of elastic compression and become liable for brittle failure in a dynamic form with mean hazard index (KRB) over 0.7, which corresponds to the high hazard category. There are also rocks and ores at the Charmitan deposit with high strength characteristics that can accumulate significant potential energy and undergo brittle failure. These rocks include quartz-mica schists, granosyenites and syenites. 
Table 1. Physical and mechanical properties of the surrounding rock margins.

\begin{tabular}{|c|c|c|c|c|c|c|c|}
\hline Rock type & $\begin{array}{l}\text { Density, } \\
\text { t/m3 }\end{array}$ & $\begin{array}{l}\text { UCS, } \\
\mathrm{MPa}\end{array}$ & $\begin{array}{l}\text { Uniaxial } \\
\text { tensile } \\
\text { strength, } \\
\mathrm{MPa}\end{array}$ & $\begin{array}{l}\text { Rock } \\
\text { brittle } \\
\text { ness }\end{array}$ & $\begin{array}{l}\text { Young } \\
\text { modulus } \\
E^{*} 10^{4}\end{array}$ & $\begin{array}{l}\text { Poisson } \\
\text { ratio }\end{array}$ & $\begin{array}{l}\text { Rock- } \\
\text { bump } \\
\text { hazard } \\
\text { specific } \\
\text { index, } \\
K_{R B} \\
\text { (conditi } \\
\text { onal } \\
\text { unit); }\end{array}$ \\
\hline $\begin{array}{l}\text { Coarse- } \\
\text { grained } \\
\text { granosyenite }\end{array}$ & $\begin{array}{l}(2,50 \div 2,53) \\
/ 2,52\end{array}$ & $\begin{array}{l}(136 \div 159,5) / \\
144,9\end{array}$ & $\begin{array}{l}(8,1 \div 9,6) \\
/ 8,6\end{array}$ & 16.8 & $\begin{array}{l}(2,8 \div 5,7) \\
/ 4,8\end{array}$ & $\begin{array}{l}(0,23 \div 0,30) \\
/ 0,23\end{array}$ & 0.89 \\
\hline $\begin{array}{l}\text { Medium } \\
\text { grained } \\
\text { granosyenite }\end{array}$ & $\begin{array}{l}(2,67 \div 2,70) / \\
2,68\end{array}$ & $\begin{array}{l}(95,2 \div 185,1) \\
/ 108,0\end{array}$ & $\begin{array}{l}(8,9 \div 13 \\
4) / 11,1\end{array}$ & 9.8 & $\begin{array}{l}(3,5 \div 7,6) \\
15,6\end{array}$ & $\begin{array}{l}(0,15 \div 0,26) \\
/ 0,21\end{array}$ & 0.88 \\
\hline $\begin{array}{l}\text { Fine grained } \\
\text { granosyenite }\end{array}$ & $\begin{array}{l}(2,55 \div 2,60) / \\
2,58\end{array}$ & $\begin{array}{l}(122 \div 133) / 1 \\
26,8\end{array}$ & $\begin{array}{l}(9,6 \div 13 \\
1) / 10,9\end{array}$ & 11.6 & $\begin{array}{l}(3,6 \div 6,1) \\
15,0\end{array}$ & $\begin{array}{l}(0,11 \div 0,28) \\
/ 0,19\end{array}$ & 0.90 \\
\hline $\begin{array}{l}\text { Carbonaceous } \\
\text {-shale. } \\
\text { silicified }\end{array}$ & $\begin{array}{l}(2,60 \div 2,65) / \\
2,63\end{array}$ & $\begin{array}{l}(142,0 \div 169,0 \\
) / 150,9\end{array}$ & $\begin{array}{l}(12,4 \div 15 \\
, 3) / 14,0\end{array}$ & 10.8 & - & - & 0.91 \\
\hline Horny slate & $\begin{array}{l}(2,67 \div 2,72) / \\
2,69\end{array}$ & $\begin{array}{l}(196,7 \div 252,4 \\
) / 206,9\end{array}$ & $\begin{array}{l}(13,2 \div 16 \\
, 4) / 14,9\end{array}$ & 14.6 & $\begin{array}{l}(4,7 \div 8,0) \\
/ 6,3\end{array}$ & $\begin{array}{l}(0,19 \div 0,30) \\
/ 0,26\end{array}$ & 0.93 \\
\hline Quartz vein & $\begin{array}{l}(2,63 \div 2,70) / \\
2,66\end{array}$ & $\begin{array}{l}(136,0 \div 183,2 \\
) / 156,2\end{array}$ & $\begin{array}{l}(5,9 \div 11, \\
3) / 8,0\end{array}$ & 19.6 & $\begin{array}{l}(7,6 \div 8,9) \\
/ 8,5\end{array}$ & $\begin{array}{l}(0,09 \div 0,13) \\
/ 0,11\end{array}$ & 0.92 \\
\hline
\end{tabular}

Note: brittleness factor is calculated by the formula $\mathrm{K}=\sigma_{-}$compr $/ \sigma_{-}$tension

\section{Conclusions}

To sum up the cited research data on physical and mechanical properties of the host rock at the Charmitan deposit, it can be concluded that the rocks of the deposit differ significantly in their lithological composition and on the whole, have reasonably high strength and elastic characteristics, which indicates their ability to accumulate significant amount of potential energy. Syenite contained in many rock varieties make them highly fragile and liable to failure in a dynamic form. In general, in terms of physical and mechanical parameters of the host rock, the Charmitan gold deposit is ranked as a burst hazardous deposit.

\section{References}

1. I.M. Petukhov Rock bursts in coal mines. Moscow, (2004).

2. T. Li, M.F. Cai, M. Cai, Int. J. Rock. Mech. Min. Sci. 44, 1149-1171 (2007).

3. I. Yu. Rasskazov, A.V. Gladyr, P.A. Anikin, V.S. Svyatetsky, B.A. Prosekin, Gornyi Zhurnal 8 (2), 9-14. (2013).

4. P. Knoll, Gerlands Beitr. Geophys. 99, 239-245 (1990). 
5. A.S. Batugin, V.N. Odintsev, K.S. Kolikov, Ev.V. Khotchenkov, Proc. of the Europ. Rock Mech. Sympos. (EUROCK-2018), Saint-Petersburg, Russia, 1, 593-598, (2018).

6. I. Yu. Rasskazov, D. S. Migunov, P. A. Anikin, A. V. Gladyr', A. A., Tereshkin, D. O. Zhelnin, J. Mining Sci. 51(3), 614-623 (2015).

7. D. Amidzic, S.K. Mupphy, G. Van Aswegen, Proc. of the 9th ISRM Congress.

8. A. Lovchikov, J. Mining Sci. 49(4), 572-575. Doi: 10.1134/S1062739149040072 (2013).

9. R.J. Durrheim, In : Proc. of the SME Annual meeting and exh., 21-24 Feb. 2010, Phoenix, Arizona. Soc.for Mining, Met. and Explor., 156-171. ISBN 978-0-87335322-9. (2010).

10. A. Batugin, V. Odintsev, K. Kolikov, Y. Lijiang, E. Khotchenkov, Proc. Surv. Geol. Min. Ecol. Manag., SGEM, 18(1.3), 319-326. Doi:10.5593/sgem2018/1.3/S03.041 (2018).

11. T.-W. Lan, H.-W. Zhang, L. Sheng, at al, Sc. World J., Article ID 516095, (2015).

12. D. Dreger, S.R. Ford, W.R. Walter, Source analysis of the Crandal Cayon, Utah mine collapse. Science 321, 217 (2008).

13. T. G. Butler, B. S. Simser, Proc. of the 9th Int. Symp. on Rockbursts and Seismicity in Mines, Santiago, Chile, 290-296 (2017).

14. I. Petukhov, I. Batugina, Bibliography of Rock Bursts. Balkema, Rotterdam (1991).

15. V.R. Rakhimov, A.N. Kazakov, Vestnik of Tashkent State Techn. Univer. 3 (2010).

16. A. Keneti, B. Sainsbury, Eng. Geol. 246, 361-373. Doi:10.1016/j.enggeo.2018.10.005 (2018).

17. A. Batugin, A. Myaskov, Y. Ignatov, E. Khotchenkov, D. Krasnoshtanov, Proc.of IOP Conf. Ser.: Earth and Environ. Sci., 221(1). Doi:10.1088/1755-1315/221/1/012089 (2018).

18. H. Marcak, G. Mutke, J. of Seismology 17(4), 1139-1148. Doi: 10.1007/s10950-0139382-3 (2013).

19. A.S. Batugin, I.M. Batugina, T. Lan, J. of Liaoning Technical University, 35(6) 561565. Doi: 10.11956/j.issn.1008-0562.2016.06 (2016).

20. G. Van Aswegen, Proc. of 8th Int. Symp. on Rockbursts and Seismicity in Mines, Keynote Lecture. Saint-Petersburg-Moscow, (2013).

21. A.S. Batugin, Proc. Rock Mech. for Natural Resources and Infrastructure Development (ISRM-14), Brasil, (to be published) (2019).

22. I.Yu. Rasskazov, B.G. Saksin, V.I. Usikov, M.I. Potapchuk, Gornyi Zhurnal 12, 13-19. Doi: 10.17580/gzh.2016.12.03 (2016).

23. R.J. Durrheim, R.I. Anderson, A. Gichowicz at al., Proc. of the 3rd Int. Seminar on Deep and High Stress Mining, 2-4 Oct. 2006, Canada (2006).

24. A.S. Batugin, E3S Web of Conferences 56, Article ID 02007, Doi: 10.1051/e3sconf/20185602007 (2018).

25. A. Batugin, V. Musina, I. Golovko, Proc.of IOP Conf. Ser.: Earth and Environ. Sci., 95, 042023. Doi :10.1088/1755-1315/95/4/042023 (2017).

26. A. S. Batugin, A Kobylkin, V Musina, K. Daniil, Proc. Surv. Geol. Min. Ecol. Manag.,SGEM, 18(1.3), 1111-1118. Doi:10.5593/sgem2018/1.3/S03.140 (2018).

27. M.P Wilson, R.J. Davies, G.R. Foulger, B.R. Julian, P. Styles, J.G. Gluyas, S. Almond, Mar. Pet. Geol. 68 1-17, http://dx.doi.org/10.1016/j.marpetgeo.2015.08.023 (2015).

28. B.G. Saksin, I.Yu. Rasskazov, B.F. Shevchenko, J. of Min. Sci., 2, 243-252 (2015).

29. J. Qu, H. Tao, Geomech. and Geoengineer., Doi:10.1080/17486025.2019.1645364 (2019)

30. A.A. Makarov, Practical geomechanics. Moscow, Mining book (2006).

31. Instruct. for the safe mining in ore and non-metallic deposits. USSR, VNIMI, (1980). 